\title{
Gastric Ulceration and Exercise Intensity in Standardbred Racehorses in Czech Republic
}

\author{
B. BEZDĚKOVÁ ${ }^{1}$, P. JAHN ${ }^{1}$, M. VYSKOČIL ${ }^{2}$, J. PLACHÝ ${ }^{3}$ \\ ${ }^{1}$ Department of Internal Medicine, Horse Clinic, Faculty of Veterinary Medicine \\ ${ }^{2}$ Department of Genetics, Faculty of Veterinary Medicine \\ ${ }^{3}$ Department of Surgery and Orthopaedics, Horse Clinic, Faculty of Veterinary Medicine University \\ of Veterinary and Pharmaceutical Sciences, Brno, Czech Republic \\ Received September 6, 2004 \\ Accepted March 3, 2005
}

\begin{abstract}
Bezděková, B., P. Jahn, M. Vyskočil, J. Plachý: Gastric Ulceration and Exercise Intensityin Standardbred Racehorses in Czech Republic. Acta Vet. Brno 2005, 74: 67-71.

The objective of our study was to determine prevalence of equine gastric ulcer syndrome (EGUS) in individual groups of Standardbred horses in the Czech Republic divided in accordance to training intensity, to determine association between training intensity and prevalence of gastric ulcers and severity of gastric ulcers in these horses. Fifty four 2-year-old or older Standardbred racehorses engaged in routine training and racing were selected for this study. Prevalence of gastric ulcers was $20.00 \%$ in Standardbred racehorses with no training intensity, $16.67 \%$ in horses in mild training, $68.42 \%$ in horses in intermediate training and $79.12 \%$ in horses in high intensity training. Significant association was proven between training intensity and occurrence of gastric ulcers. Positive correlation between training intensity and gastric ulceration severity was proven as well. From the results we concluded that gastric ulcers are common in Standardbred horses in training in Czech Republic. Their prevalence and severity is dependent on the training intensity.
\end{abstract}

Gastric ulcer, prevalence, training, standardbred, racehorse, Czech Republic

Gastric ulceration in horses (equine gastric ulcer syndrome - EGUS) has aroused interest during the last decades due to new intravital diagnostic procedures and results of intensive study of ethiopathogenesis and therapy of this disease.

In many studies, high prevalence of the disease in racehorses and horses in active race training was proven. The prevalence of EGUS ranges from $66 \%$ (Ha m mond et al.1986) to more than $90 \%$ (Murray 1994). Horses used for pleasure, riding lessons or show have lower prevalence (37\%) and severity of gastric ulcers (Murray et al. 1989). Prevalence of EGUS in the Czech Republic is $62.96 \%$ (Bezděková et al. 2004, parallel publication).

It was proven that the prevalence and severity of gastric ulceration increases with the duration of race training or endurance training (Murray 1994; Orsini and Pipers 1997). This is consistent with pathomorphological findings in 195 Thoroughbred racehorses reported by Hammond et al. (1989). In this study, the prevalence of EGUS was higher in horses in active training and racing (80\%) than in those that were not in training $(37 \%)$, and similar results were reported by Murray et al. (1989). Association between occurrence of EGUS and training intensity has not been evaluated in Middle Europe yet.

The cause of gastric ulcers is still unknown. Diet and feed management are considered potential risk factors. Lower prevalence and severity of gastric ulcers occur in horses which are kept on pasture with continuous feed intake than in those which are fed with high-grain diet. Administration of nonsteroidal anti-inflammatory drugs was reported as a cause of gastric ulceration in many species (MacAllister et al. 1993), however the occurrence of ulcers is high even in horses with no history of drug use (Hammond et al. 1986).

Stress associated with training and racing, stress of various etiologies in foals, or stress

Address for correspondence:

MVDr. Barbora Bezděková

Large Animal Clinic, Faculty of Veterinary Medicine

University of Veterinary Amd Pharmaceutical Sciences

Palackého 1-3, 612 ?42 Brno, Czehc Republic
Phone: +420541562380

Fax: +420 541562395

E-mail: bbezdekova@vfu.cz

http://www.vfu.cz/acta-vet/actavet.htm 
associated with illness are possible risk factors in pathogenesis of gastric ulcers. According to positive correlation between training and racing intensity and gastric ulcer occurrence, it is supposed that stress associated with these activities plays an important role in gastric ulcer pathogenesis.

Nevertheless it is considered a contributing factor only for ulcers found in the glandular portion of the stomach and ulceration in the squamous part after exposure to stress was not yet confirmed (Furr et al. 1992). Reliable sources of information on association between stress and equine gastric ulcer syndrome are not available especially due to problematic quantification and objectification of stress.

In summary, strenuous exercise as well as diet and feed management were proven important contributing factors in the prevalence of gastric ulcers.

The objective of our study was:

1. to determine prevalence of EGUS in individual groups of Standardbred horses divided in accordance to training intensity;

2. to determine association between training intensity and prevalence of gastric ulcers in Standardbred horses in the Czech Republic;

3. to determine association between training intensity and severity of gastric ulcers in Standardbred racehorses with known prevalence of individual ulcer severity scores.

\section{Examined horses}

\section{Materials and Methods}

Fifty four 2-year-old or older Standardbred racehorses engaged in routine training and racing were selected for this study. The horses were stalled at 5 trainers. All horses were in active training for at least six months. All horses were examined within the first 10 days after the end of racing season which finishes in the first half of November in the Czech Republic. Overall prevalence of EGUS (62.96\%) and occurrence of individual ulcer severity scores were determined in the monitored group (B ezděková et al. 2004, parallel publication). An adapted gastric ulcer severity scoring system by $\mathrm{Nadeau}$ et al. (2002) was used.

In each examined horse intensity of exercise was classified in 4 grades. Grades were set according to volume of fast work in 1 week, number of racings in 1 month, and intensity of endurance training.

- No training intensity:

Horses were not put in sulkies or their daily exercise dose of slow pace work in the sulky did not exceed more than $6 \mathrm{~km}$ of slow trotting. Horses did not participate in fast pace work or racing within last 2 months.

- Mild training intensity:

Less than 1 fast pace work per week, endurance training varied from 6 to $10 \mathrm{~km}$ of slow trotting a day for at least 5 days a week. Respectively, horses were trained more intensively but less than 5 days weekly. Horses participated in 1 racing within last 2 months at least.

- Intermediate training intensity:

Horses participated at least in 1 fast pace work per week and slow pace work on distance from 10 to $15 \mathrm{~km}$ more than 5 times a week. They participated in 2 to 4 racings within last 2 months.

- High training intensity:

Horses participated at least in 2 st pace works weekly, slow pace work exceeded $15 \mathrm{~km}$ more than 4 times per week or average number of racings was 0.75 to 1.0 per week.

According to training intensity, horses were selected to the following groups: No training 5 horses $(9.26 \%)$, mild training 6 horses $(11.11 \%)$, intermediate training 19 horses $(35.19 \%)$, and high training intensity 24 horses $(44.44 \%)$ (Table 1).

Parameters evaluating influence of the additional factors for occurrence and severity of EGUS (feeding, diet and etc.) will be described in following studies.

Statistical analyses

A database was made by use of obtained anamnesis and examination results. Overall prevalence of EGUS was used from the former study (Bezděková et al. 2004, parallel publication). Occurrence of EGUS was derived in individual training intensity categories. The obtained results were expressed in percentage (Table 1).

Association between occurrence or severity of gastric ulcers and exercise intensity was analyzed in each training category.

The obtained data was statistically analyzed using $\chi^{2}$ test and its modifications for low periodicity (Fischer's test, G-test), and by use of non-parametric tests (Wilcoxon's test, Steel-Dwass test and Spearman's rank correlation 
test). Commercially available software (Excel, KyPlot) and online data analysis available on internet were used for statistical analyses.

Table 1. Distribution (No.[\%]) of horses according to race training intensity in monitored population of Standardbred racehorses; distribution (No.[\%]) of horses with gastric ulcers (EGUS positive) according to training intensity; distribution (No.) of individual EGUS severity scores in monitored population according to training intensity

\begin{tabular}{|l|c|c|c|c|c|c|c|}
\hline Training & \multirow{2}{*}{$\begin{array}{c}\text { No. (\%) of } \\
\text { intensity }\end{array}$} & \multicolumn{2}{|c|}{$\begin{array}{c}\text { No. (\%) of EGUS } \\
\text { positive horses }\end{array}$} & \multicolumn{5}{|c|}{ EGUS severity } \\
\cline { 4 - 8 } & & & 0 & $\mathbf{1}$ & $\mathbf{2}$ & $\mathbf{3}$ & $\mathbf{4}$ \\
\hline No training & & $1(20 \%)$ & 4 & 1 & 0 & 0 & 0 \\
\hline intensity & $5(9.26 \%)$ & $1(16.67 \%)$ & 5 & 1 & 0 & 0 & 0 \\
\hline $\begin{array}{l}\text { Mild training } \\
\text { intensity }\end{array}$ & $6(11.11 \%)$ & $13(68.42 \%)$ & 6 & 6 & 5 & 2 & 0 \\
\hline $\begin{array}{l}\text { Intermediate } \\
\text { training } \\
\text { intensity }\end{array}$ & $19(35.19 \%)$ & $19(79.12 \%)$ & 5 & 8 & 9 & 2 & 0 \\
\hline $\begin{array}{l}\text { High training } \\
\text { intensity }\end{array}$ & $24(44.44 \%)$ & $34(62.96 \%)$ & 20 & 16 & 14 & 4 & 0 \\
\hline Total & $54(100 \%)$ & & & & & & \\
\hline
\end{tabular}

\section{Results}

1. Prevalence of gastric ulcers was $20.00 \%$ in Standardbred racehorses with no training intensity, $16.67 \%$ in horses in mild training, $68.42 \%$ in horses in intermediate training and $79.12 \%$ in horses in high intensity training (Table 1 ).

2. Significant association was proven between training intensity and occurrence of gastric ulcers (median 3 in EGUS positive horses; median 2 in EGUS negative horses Wilcoxon's test; $p$ ' $<0.0079$ - G-test).

3. Positive correlation between training intensity and gastric ulceration severity was proven ( $\mathrm{rs}=0.4105 ; p=0.003$ ). Note: Spearman's correlation coefficient.

\section{Discussion}

Our objective was to determine the prevalence of gastric ulcers in accordance with training intensity. The study was performed in a group of 54 Standardbred racehorses where overall occurrence of gastric ulcers was 62.96\% (B ezděková et al. 2004, parallel publication). The group of 54 horses was divided into 4 categories according to training intensity (no, mild, intermediate and high training intensity). Individual exercise intensities were determined by volume of fast pace work, slow pace work, and racing. The lowest occurrence of EGUS was in horses in intermediate intensity of training $(16.67 \%)$ and highest occurrence was in horses in high intensity training $(79.12 \%)$. Occurrence of ulcers in horses with no training intensity was $20.00 \%$ which was comparable to the group in training of intermediate intensity. There was 1 EGUS positive horse in the intermediate exercise intensity group (out of 5 horses) and 1 positive horse in intermediate training intensity group (out of 6 horses) (Table 1). The prevalence of gastric ulceration in categories of no training intensity and intermediate training intensity could be influenced with the low number of horses in these groups. The prevalence of EGUS in the group of intermediate training intensity was $68.42 \%$ and in the group of high intensity training was $79.12 \%$. These results are comparable to the prevalence of EGUS in Thoroughbred racehorses in intensive training (without being divided into individual training intensity categories) reported by Hammond et al. (1986). According to this study, the prevalence 
of gastric ulcers in horses in training was $80 \%$ whereas in non-trained horses was $37 \%$. Murray et al. (1989) reported 78\% prevalence of EGUS in racehorses in active race training. However, all examined horses showed some non-specific clinical signs of gastric ulceration. Rabuffo et al. (2002) monitored prevalence of ulcers in 224 two-year-old and three-year-old Standardbred racehorses in the United States which was $87 \%$. Horses in this study did not show any non-specific clinical signs of gastric ulceration. No information on gastric ulceration prevalence in Middle and Eastern Europe is available. The prevalence of EGUS in race bred horses in the world vary from 66\% (Hammond et al. 1986) to over $90 \%$ (Murray et al. 1994). The high prevalence of this disease in the population of racehorses was confirmed in our study as well.

The second objective of our study was to determine possible association between exercise intensity and EGUS occurrence in the monitored group of horses. Our last objective was to evaluate possible association between training intensity and severity of gastric ulcers.

The occurrence of gastric ulcers significantly increased with training intensity. Also severity of ulcers significantly increased with training intensity or more severe gastric ulcer scores occurred in more horses with an increase in training intensity. Our results correspond with Murray et al. (1996) who proved positive correlation between the duration of training and occurrence, or severity, of gastric ulceration in 35 Thoroughbred racehorses. However, significant association was found just between training intensity and changes in the squamous portion of gastric mucosa. Association between changes in the glandular part of gastric mucosa and duration of training was not significant. In our study of 54 Standardbred racehorses, changes in the glandular gastric mucosa were not evaluated (B ezděková et al. 2004, parallel publication). We should emphasize that most lesions which are characteristic for EGUS are localized in squamous portion of the stomach (S and in et al. 2000). Presumably, the non-secretory squamous portion of gastric mucosa predisposes to less effective protection and is more likely to develop lesions than the glandular portion. On the contrary, the gastric glandular mucosa which is responsible for complete gastric secretion of protective or aggressive substances is more resistant to ulceration (Murray 1997). Positive correlation between endurance exercise in racehorses and prevalence, or severity, of gastric ulcers was reported by Murray (1994) or Orsini and Pipers (1997).

Besides training intensity, diet and feed management are often discussed as possible risk factors in gastric ulcer occurrence. Pasture feeding is associated with lower incidence, whereas feeding more concentrates and less hay are associated with higher incidence of gastric ulceration, lower stomach pH (Murray and Schusser 1992) and higher blood gastrin levels (S my th et al. 1998). Horses secrete gastric acid continuously, even when they are not eating (Campbell-Thomps on and Merrit 1987). Therefore, feeding frequency and management play an important role in gastric mucosa damage. Nevertheless, according to our clinical experience, horses in no training intensity, kept on pasture and not fed with concentrated diet can also show signs of severe gastric ulceration. Risk factors in these animals are not known.

In conclusion, association between intensity of race training and prevalence, or severity, of gastric ulcers was evaluated in our study. In 54 Standardbred racehorses divided into 4 groups in accordance with training intensity, correlation between exercise intensity and occurrence, or severity, of ulcers was proven. Our results correspond with other published studies. We also expect influence of diet and feed management in pathogenesis gastric ulceration. However, exceptions are possible not only in the horses which are predisposed to EGUS (racehorses) but also in horses in relatively low risk of EGUS development (no exercise, pasture feeding). 


\section{Syndrom gastrické ulcerace u klusáků v České Republice a jeho závislost ke stupni zátěže}

Cílem studie bylo stanovení prevalence ulcerací žaludku (EGUS) u jednotlivých skupin dostihových klusáků v České republice rozdělených podle intenzity zátěže a dále zjištění případné souvislosti mezi výskytem a stupněm závažnosti gastrických ulcerací a intenzitou tréninkové zátěže. Pro studii bylo využito 54 dvouletých a starších klusáků v tréninku. Prevalence EGUS u koní bez zátěže byla 20,00 \%, prevalence EGUS u koní v mírné zátěži byla 16,67 \%, u koní ve střední zátěži 68,42 \% a u koní ve vysoké zátěži 79,12 \%. Byla zjištěna statisticky významné souvislost mezi intenzitou zátěže a výskytem žaludečních vředů a pozitivní korelace mezi intenzitou zátěže a stupněm závažnosti EGUS.

Vředy žaludeční sliznice jsou častým onemocněním u dostihových klusáků v České republice. Jejich výskyt a stupeň závisí na intenzitě tréninku.

\section{Acknowledgements}

This study was supported by Internal Grant Agency of the University of Veterinary and Pharmaceutical Sciences Brno, No. 9/2003/ FVL.

\section{References}

BEZDĚKOVÁ, B, JAHN, P, VYSKOČIL, M, PLACHÝ, J 2005: Prevalence of equine gastric ulceration syndrome in standardbred horses in the Czech Republic. Acta Vet Brno 74: 59-65

CAMPBELL-THOMSON, ML, MERRITT, AM 1987: Effect of ranitidin on gastric acid secretion in young male horses. Am J Vet Res 48: 1511-1515

FURR, MO, MURRAY, MJ, FERGUSON, DC 1992: The effects of stress on gastric ulceration, T3, T4, reverse $\mathrm{T} 3$ and cortisol in neonatal foals. Equine Vet $\mathrm{J}$ 24: 37-40

FURR, MO, TAYLOR, L, KRONFELD, D 1994: The effects of exercise training on serum gastrin responses in the horse. Cornell Vet 84: 41-45

HAMMOND, CJ, MASON, DK, WATKINS, KL 1986: Gastric ulceration in mature Thoroughbred horses. Equine Vet J 18:284-287

JOHNSON, B, CARLSON, GP, VATISTAS, N 1994: Investigation of the number and location of gastric ulcerations in horses in race training submitted to the Kalifornia racehorse postmortem program. In Proceedings: Am Assoc Equine Pract: 123-124

MACALLISTER, CG, MORGAN, SJ, BORNE, AT, POLLET, RA 1993: Comparison of adverse effects of phenylbutazone, flunixin meglumine and ketoprofen in horses. J Am Vet Med Ass 202: 71-77

MURRAY, MJ, GRODINSKY, C, ANDERSON, CW 1989: Gastric ulcers in horses: a comparison of endoskopic findings in horses with and without clinical signs. Equine Vet J Suppl 7: 68-72

MURRAY, MJ, SCHUSSER, G 1992: Application of gastric pH-metry in horses: measurement of 24 hour gastric $\mathrm{pH}$ in horses fed, fasted and treated with ranitidin. J Vet Intern Med 6: 133

MURRAY, MJ 1994: Gastric ulcers in adult horses. Comp Cont Educ Pract Vet 16: 792-794, 797

MURRAY, MJ, SCHUSSER, GF, PIPERS, FS, GROSS, SJ 1996: Factors associated with Gastric lesions in Thouroughbred racehorses. Equine Vet J 28: 368-374

MURRAY, MJ 1997: Gastroduodenal ulceration. In: Current Therapy in Equine Medicine, 4th edn, Ed:N.E. Robinson: 191-197

ORSINI, JA, PIPERS, FS 1997: Endoscopic evaluation of the relationship between training, racing, and gastric ulcers. Vet Surg 26: 424

SANDIN, A, SKIDELL, J, HAGGSTORM, J, NILSSON, G 2000: Postmortem findings of gastric ulcers in Swedish horses older than age one year: a retrospective study of 3715 horses (1924-1996). Equine Vet J 32: $36-42$

SMYTH, GB, YOUNG, DW, HAMMOND, LS 1988: Effects of diet and feeding of post-prandial serum gastrin and insulin concentrations in adult horses. Equine Vet J Suppl 7: 56-59 